\title{
Trust in Seller and Trust in Website as A Determiner of Consumer Buying Interest
}

\author{
Lisnawati $^{1, *}$ Agus Rahayu ${ }^{2,}$ N. Fadilah ${ }^{3}$
}

\author{
${ }^{1}$ Universitas Pendidikan Indonesia \\ ${ }^{2}$ Universitas Pendidikan Indonesia \\ ${ }^{3}$ Universitas Pendidikan Indonesia \\ ${ }^{*}$ Corresponding author. Email: lisnawati@upi.edu
}

\begin{abstract}
The purpose of this study is to obtain empirical evidence about the effect of trust in sellers and trust in the website is shaping repurchase intention. The type of research used is descriptive verification by drawing, and exposure of the variable-variables studied and then drawing conclusions. The research object that is the dependent variable is the repurchase intention, trust in the seller, and trust in the website as independent variables. The population in this study were followers of Fashion e-commerce in Indonesia. Sampling in this study used a simple random sampling method using a purposive sampling technique. The test instrument is done by validity test and reliability test, and the analysis technique used is path analysis. The results show a partial and simultaneous significant effect between trust in sellers and trust in websites on repurchase intention.
\end{abstract}

Keywords: trust, seller, website, consumer buying interest, consumer.

\section{INTRODUCTION}

Repurchase Intention is an essential element for marketing due to a shift in orientation, which initially focused on creating consumer purchasing decisions to encourage motivated consumers to repurchase [1]. Repurchase Intention is essential to the company because retaining an old customer will be cheaper than attracting a new customer [2].

Marketers are generally interested in investigating the effect of marketing on repurchase intentions; previous research includes various products such as online auctions, online shops, luxury goods, hotels, resorts and spas, tourism services, banking, online auctions, and cosmetics [3]. Marketers are generally interested in investigating the effect of marketing on repurchase intentions; previous research includes various products such as online auctions, online shops, luxury goods, hotels, resorts and spas, tourism services, banking, online auctions, and cosmetics. [2].

As a relatively new medium for business, ecommerce websites have changed the way customers buy products or services. An active e-commerce buyer globally, Indonesia ranks 26, with a total of $27 \%$ of internet users in Indonesia are active buyers in the ecommerce market. The increasing use of the internet every year places Indonesia as a potential market for doing online business or e-commerce [4]. Customers start buying products or services from an e-commerce website instead of going to a physical store [5]. Apart from the development of e-commerce, the competition among online retailers is becoming more intense. Buyback intentions have a significant impact on online retailers' profits [5].

Many factors influence a person's interest in shopping online, such as ease of transaction, saving 
time, and several other factors that ultimately generate interest in consumers to buy the product or not. Purchase intention is the stage of the consumer's tendency to act before the buying decision is implemented [5]. Purchase intention can arise because the products sold are under the wishes of the buyer. When a consumer has made a purchase, there will be a repurchase intention based on past purchasing experience.

The high demand and opportunities that arise in the clothing industry resulting in the proliferation of online retail globally and primarily in Indonesia. Along with this, it is evident that now more and more consumers are accustomed to using the internet in their daily activities, where one of the activities is trading online (ecommerce).

The level of repurchase intention can be represented by the brand's level most often used and consumers' level to recommend it. Consumers' intention to repurchase stems from the loyalty inherent in the relationship between customer satisfaction and the expectation to buy [6]. The rise of fashion e-commerce companies in Indonesia forces its market players to continue to increase sales so that they can continue to be in the top position. The measure of repurchase intention usually refers to consumers' willingness to repurchase products with the same brand from the same company in the future [7].

The decrease in the number of visitors shows visitors' low interest to revisit the Fashion e-commerce website, indirectly illustrates the occurrence of dissatisfaction when visiting or making purchases, resulting in low consumer intention to visit again and make repurchases on the Fashion e-commerce web-site. Consumers involved in online purchasing are usually concerned about their shopping safety [8]. When consumers shop online, the higher the level of consumer confidence, the stronger the intention to buy products from the brand [9].

When someone is interested in repurchase intention, there are several things that consumers consider. It is stated that price and service quality factors can influence repurchase intention [10], trust in sellers, and trust in websites positively on stimulating consumers to make repurchase intention [1].

Trust in sellers and trust in websites are factors that are used to overcome the problem of repurchase intention in this study because, in the marketing of trust in seller services, trust in sellers arises from pleasure and happiness when the shopping process is complete. If the consumer feels happy and grows stimuli during the shopping experience, they are very likely to engage in subsequent shopping behavior. Consumers will search further, engage in unplanned purchases and search for more product categories [11]. Trust in a website is a form of convenience and gives consumers flexibility in choosing online products. The implication of trust has a significant impact on consumers' desire to conduct transactions via the inter-net.

Fashion e-commerce is one of e-commerce that focuses on consumer satisfaction by paying attention to factors that can shape consumer perceived repurchase intention through sellers' reputation, the perceived size of the seller, website reputation, and per-ceived website size increase repurchase intention. On the Fashion ecommerce website. Implementing an appropriate marketing strategy, Fashion e-commerce realizes the importance of customer perceptions in choosing and comparing products with other offerings and the importance of customer experience. Fashion ecommerce strives to make products that can compete with competitors and provide easy access to shopping on the website. Fashion e-commerce has the characteristics of a website that can help consumers view and search for goods according to the category and price range. On the Fashion e-commerce website, live chat is available to make it easier for consumers to find products.

Based on this description, the marketing program implemented by Fashion e-commerce follows the trust in seller and trust in the website, but in its implementation, there are still several programs that are not running as expected. This is indicated by the low repurchase intention of consumers. The researcher felt the need to conduct research to determine whether trust in sellers and trust in websites was influential in forming repurchase intention, so the researcher conducted a study with the title.

\section{METHODS}

The approach used in this study is the marketing management approach, especially regarding the influence of trust in sellers and trust in websites on the repurchase intention of online fashion site customers. As for the object of research as the dependent variable (endogenous), namely repurchase intention including dimensions, i3 Furthermore, the research object as an independent (exogenous) variable, namely trust in sellers with dimensions of price advantage, product differentiation, reputation, social interaction, language effort, and hedonic effort. Trust in websites with the dimensions of security and privacy, information and technology quality, and traits. The unit of analysis used as respondents in this study is visitors to the startup Fashion e-commerce website.

This research was conducted in less than one year, so the method used was cross-sectional. Based on the variables studied, this type of research is verification 
research. The data used in this study consisted of primary data and secondary data.

The minimum sample size in this study was determined with $\alpha=0.05$. The minimum sample size (n) of 249 was rounded to 250 . The sampling in this study used a simple random sampling technique. This method is done when members of the popula-tion are considered homogeneous. Simple random sampling can be done by lottery, selecting numbers from a random number list, and so on. The question-naire's questions were tested for validity beforehand to ensure similarity between the collected data and the data that occurred on the object under study. The reliability so that the distributed questionnaire had consistency, accuracy, and predictability of a measuring instrument. The data analysis technique used to see the effect of trust in sellers and trust in websites on repurchase intention is a path analysis technique.

\section{RESULT AND DISCUSSION}

This research hypothesis testing was conducted to determine the influence of trust in sellers and trust in websites in forming repurchase intention. This research hypothesizes that trust in sellers and trust in websites have a simultaneous and partial effect on repurchase intention. This hypothesis was tested simultaneously or partially using SPSS 23.0 for windows. The results of testing the hypothesis as a whole (simultaneously) can be seen in Table 1 below:

Table 1. Simultaneos Test Result

\begin{tabular}{|l|l|l|l|l|}
\hline \multicolumn{1}{|c|}{$\begin{array}{c}\text { Alternative } \\
\text { Hypothesis }\end{array}$} & F count & F table & Decision & Conclusion \\
\hline $\begin{array}{l}\text { trust in sellers } \\
\text { and trust in } \\
\text { websites affect } \\
\text { repurchase } \\
\text { intention }\end{array}$ & 501,019 & 3,879 & $\begin{array}{l}\mathrm{H} 0 \\
\text { rejected }\end{array}$ & Significant \\
\hline
\end{tabular}

The table above shows the test for the F test taken from Anova with a probability level $(\mathrm{Sig})=0,000$ because Sig $\leq 0.05$, the decision is $\mathrm{H} 0$ rejected, meaning that simultaneously (overall) there is a simultaneous influence between trust in sellers and trust in websites in forming a repurchase intention on consumer members of the Facebook fan page Fashion e-commerce.

The test results give significant results, so to find out the independent variables that have a significant effect on repurchase intention, partial testing can be continued. The following is the correlation matrix between trust in sellers and trust in websites in shaping repurchase intention for consumers who are members of the Facebook fan page. Fashion e-commerce can be seen in Table 2 below.:

Table 2. Matrix Correlation Between Trust In Seller And Trust In Website Towards Repurchase Intention

\begin{tabular}{|c|l|l|l|}
\hline Variable & $\begin{array}{c}\text { Trust in } \\
\text { Seller }\end{array}$ & $\begin{array}{c}\text { Trust in } \\
\text { Website }\end{array}$ & $\begin{array}{c}\text { Repurchase } \\
\text { Intention }\end{array}$ \\
\hline Trust in Seller & 1 & 0,896 & 0,856 \\
\hline Trust in Website & 0,896 & 1 & 0,884 \\
\hline $\begin{array}{c}\text { Repurchase } \\
\text { Intention }\end{array}$ & 0,856 & 0,884 & 1 \\
\hline
\end{tabular}

Table 2 shows the relationship of each variable consisting of trust in sellers and trust in websites. Based on the correlation matrix results between trust in sellers and trust in websites in forming repurchase intention for consumers who are members of the Fashion ecommerce Facebook fan page, the correlation results are obtained sequentially. Consumers who are members of Facebook fan page trust in sellers (0.856) and trust in websites (0.884), whereas trust in sellers and trust in websites correlates (0.896). The following Table 3 shows the calculation results of the following partial tests:

Table 3. Results Of Partial Hypothesis Testing

\begin{tabular}{|c|l|l|l|l|l|}
\hline Hypothesis & $\begin{array}{c}\text { Path } \\
\text { Coefficient }\end{array}$ & t count & t table & Sig. & Decision \\
\hline $\begin{array}{c}\text { Trust in } \\
\begin{array}{c}\text { Seller } \\
\rightarrow \text { Repurcha } \\
\text { se Intention }\end{array}\end{array}$ & 1.212 & $\begin{array}{l}6,80 \\
1\end{array}$ & $\begin{array}{l}3.87 \\
9\end{array}$ & $\begin{array}{l}0,00 \\
0\end{array}$ & $\begin{array}{l}\mathrm{H} 0 \\
\text { rejected }\end{array}$ \\
\hline $\begin{array}{c}\text { Trust in } \\
\text { website } \\
\rightarrow \text { Repurcha } \\
\text { se Intention }\end{array}$ & 0,654 & 8,93 & 3.87 & 0,00 & $\begin{array}{l}\mathrm{H} 0 \\
\text { rejected }\end{array}$ \\
\hline
\end{tabular}

Based on the table above, it can be seen that the $\mathrm{t}$ value for the variables trust in sellers and trust in websites is greater than the table. This means that the two variables have a significant effect on repurchase intention. The effect of trust in sellers and trust in websites affects repurchase intention is significant. The path diagram for this hypothesis can be described as follows:

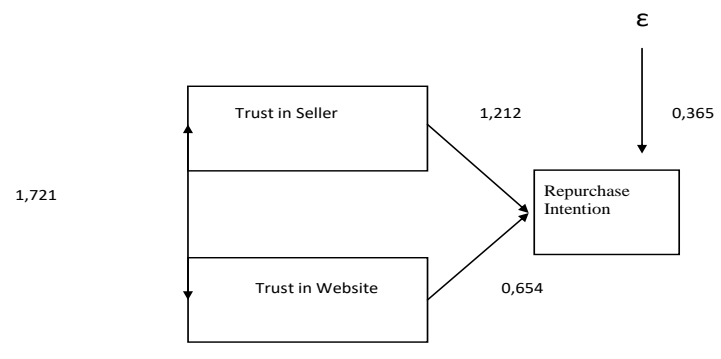

Figure 1. Trust in seller test diagram and trust in website in forming repurchase intention

The total coefficient of determination (R2) is known from the calculation can be seen in the $\mathrm{R}$ square column as listed in Table 4 as follows: 
Table 4. Determination Coefficient The Influence Of Trust In Sellers On Repurchase Intention

\begin{tabular}{|c|c|c|c|c|}
\hline \multicolumn{5}{|c|}{ c } \\
\hline Model & $\boldsymbol{R}$ & $\begin{array}{c}\boldsymbol{R} \\
\text { Square }\end{array}$ & $\begin{array}{c}\text { Adjusted } \boldsymbol{R} \\
\text { Square }\end{array}$ & $\begin{array}{c}\text { Std. Error of the } \\
\text { Estimate }\end{array}$ \\
\hline 1 & $0,856^{\mathrm{a}}$ & 0,732 & 0,731 & 12,20277 \\
\hline
\end{tabular}

Predictors: (Constant) trust in seller $\left(\mathrm{x}^{1}\right)$

Based on the table above, it can be seen that the total coefficient of determination or the partial influence of endogenous variables is 0.732 , and if it is presented at $73.2 \%$, it means that the influence of trust in sellers on repurchase intention is in a strong category. The coefficient of determination of the total sub variable trust in the website on repurchase intention can be seen in Table 5 as follows.

Tabel 5. Total Trust In Website Determination Coefficient Against Repurchase Intention

\begin{tabular}{|l|c|c|c|c|}
\hline \multicolumn{5}{|c|}{$\mathbf{c}$} \\
\hline Model & $\boldsymbol{R}$ & $\boldsymbol{R}$ Square & $\begin{array}{c}\text { Adjusted } \boldsymbol{R} \\
\text { Square }\end{array}$ & $\begin{array}{c}\text { Std. Error of the } \\
\text { Estimate }\end{array}$ \\
\hline 1 & $0,854 \mathrm{a}$ & 0,782 & 0,781 & 5,74009 \\
\hline
\end{tabular}

Based on the table above, it can be seen that the total coefficient of determination or the effect of endogenous variables partially is 0.782 , and if it is presented it is $78.2 \%$, it means that the effect of trust in the website on repurchase intention is in a strong category. Based on the table above, it can be seen that the total coefficient of determination or the partial endogenous effect of the trust in seller and trust in website variables on repurchase intention is calculated to determine the direct and indirect effect between the dimensions. This is described in Table 6 below:

Table 6. Coefficient Testing Results For Direct And Indirect Links Of Influence

\begin{tabular}{|c|l|l|l|l|c|}
\hline Variable & $\begin{array}{c}\text { Path } \\
\text { coefficient }\end{array}$ & $\begin{array}{c}\text { Direct } \\
\text { Influence }\end{array}$ & \multicolumn{2}{|c|}{$\begin{array}{c}\text { Indirect Influence } \\
\text { Through }\end{array}$} & $\mathbf{R}^{\mathbf{2}}$ \\
\hline & & & $\begin{array}{c}\text { Trust } \text { in } \\
\text { Seller }\end{array}$ & $\begin{array}{l}\text { Trust in } \\
\text { Website }\end{array}$ & \\
\hline $\begin{array}{c}\text { Trust in } \\
\text { Seller }\end{array}$ & 1,212 & 0,320 & - & 0,275 & 0,297 \\
\hline $\begin{array}{c}\text { Trust in } \\
\text { Website }\end{array}$ & 0,654 & 0,399 & 0,275 & - & 0,337 \\
\hline & Total & 0,719 & & & 0,634 \\
\hline
\end{tabular}

Based on Table 6, it can be seen that there is a direct and indirect effect of trust in sellers and trust in websites on repurchase intention. The most significant influence partially is between trust in the website on repurchase intention of 0.339 , while the indirect effect of trust in the website on repurchase intention through trust in seller variable is 0.275 . The influence of the trust in seller variable on repurchase intention is 0.320 , and the indirect effect of trust in sellers through trust in websites on repurchase intention is 0.275 . These calculations indicate that the exogenous variables trust in seller and trust in the website are very influential on the endogenous variable repurchase intention. After knowing this, trust in sellers as the most dominant dimension in influencing repurchase intention must be considered and further enhanced, while trust in websites as a non-dominant dimension must be improved and further enhanced. It can be seen that the total path coefficient between trust in sellers and trust in websites with $\mathrm{R}$ square is 0.689 . So that it can be seen the value of the residual coefficient through the following formula:

$$
\begin{gathered}
\rho_{\mathrm{Y} \varepsilon}=\sqrt{1-R^{2 \mathrm{Y}(\mathrm{X} 1, \mathrm{X} 2, \mathrm{X} 3)}} \\
\rho_{\mathrm{Y \varepsilon}}=\sqrt{1-0,634} \\
\rho_{\mathrm{Y} \varepsilon}=\sqrt{0,365}=0,604
\end{gathered}
$$

These results indicate that trust in sellers and trust in websites simultaneously affects repurchase intention, $63.4 \%$. While the influence from outside which was not examined (0.604) $2=0.365 \times 100 \%=36 \%$ influenced by other variables not included in this study.

Trust in the seller is an essential factor in using the website. This affects consumers' repurchase intention process, who want them to find and select goods that meet their needs [12]. The results showed that there was a significant influence, namely price advantage, product differentiation, social interaction, reputation hedonic effort, and language effort on the repurchase intention variable on the Fashion e-commerce website simultaneously.

In the knowledge of consumers in a website's character or characteristics, satisfaction can differentiate products from one another. Knowledge about website reputation is a crucial conceptual variable in consumer behavior and is influenced by information gathering. This helps consumers to make purchasing decisions. Reference [13] states that product knowledge is an intrinsic clue that is very important for consumers to make repurchase decisions.

E-commerce activities and smartphone users will rely on the buyer's ability to interact with computers. In other words, the decision to buy back on the website is the ability or ability of a buyer to be able to interact with a computer or use social media to help him make decisions so that consumers must be able to interact with the computer, so that information about the product to be purchased is obtained as desired [14].

Based on this explanation, there is a significant influence between trust in sellers and trust in websites on repurchase intention if they are linked together. This is under the theory, which states that trust in sellers and trust in websites are essential in influencing repurchase decisions on websites. Trust in seller, user quality, criteria, information, and technology are significantly related to user commitment and purchase decision [15] 
There are factors such as trust, quality, information, criteria, technology, and company reputation that substantially affect consumer repurchase decisions [16].

\section{CONCLUSION}

Trust in sellers has a positive and significant influence on visitors' repurchase intention to the Fashion e-commerce website in Indonesia. This means that trust in the seller is a significant explanation for repurchase intention. This shows that the better the seller's trust is given, the better the repurchase intention. Trust in the website has a positive and significant influence on visitors' repurchase intention to the Fashion e-commerce website in Indonesia. Trust in the website is a significant explanation for repurchase intention. This shows that the better the seller's trust is given, the better the repurchase intention.

The author recommends that Fashion e-commerce still maintains, supervises, and re-enhances trust in sellers by providing experience through hedonic efforts, language effort (price advantage), product differentiation, social interaction and reputation, and trust in websites with experience through security and privacy, information and technology quality and traits to support business development

\section{REFERENCES}

[1] M.H. Hsu, C.M. Chang, K.K. Chu, and Y.J. Lee, "Determinants of repurchase intention in online group-buying: The perspectives of DeLone \& McLean is success model and trust," Comput. Human Behav., 2014.

[2] E.F.T. Yuen and S. S.L. Chan, "The effect of retail service quality and product quality on customer loyalty," J. Database Mark. Cust. Strateg. Manag., 2010.

[3] E.E. Izogo, "Structural equation test of relationship quality: Repurchase intention - willingness to recommend framework in retail banking," Int. J. Emerg. Mark., 2016.

[4] M. Tatang and Mudiantono, "The impact of website design quality, service quality, and enjoyment on repurchase intention through satisfaction and trust bachelor thesis economics and business faculty," Diponegoro J. Ofmanagement, 2017.
[5] C. Xu, D. Peak, and V. Prybutok, "A customer value, satisfaction, and loyalty perspective of mobile application recommendations," Decis. Support Syst., 2015.

[6] Y. Yi and S. La, "What influences the relationship between customer satisfaction and repurchase intention? investigating the effects of adjusted expectations and customer loyalty," Psychol. Mark., 2004.

[7] Y H. Fang, C.M. Chiu, and E.T.G. Wang, 'Understanding customers' satisfaction and repurchase intentions: An integration of IS success model, trust, and justice," Internet Res., 2011.

[8] K. Choon Ling, D. Bin Daud, T. Hoi Piew, K.H. Keoy, and P. Hassan, "Perceived risk, perceived technology, online trust for the online purchase intention in Malaysia,” Int. J. Bus. Manag., 2011.

[9] L. Zhang, "The path analysis of online interpersonal interaction on purchase intention based on two-factor structure of trust and distrust," 2017.

[10] D. Yulistyarini, A. Subagio, H. Paramu, and B. Irawan, "Customer repurchase intention and satisfaction in online shopping," International Business Management. 2017.

[11] T.L. Childers, C.L. Carr, J. Peck, and S. Carson, "Hedonic and utilitarian motivations for online retail shopping behavior," J. Retail., 2001.

[12] M. Chih-Hung, E. Shih-Tse, J. Ming-Sung, and A. Fei-Long, "Information quality, online community and trust: A study of antecedents to shoppers' website loyalty," Int. J. Electron. Mark. Retail., 2009.

[13]C. Lin and W. Lekhawipat, "Factors affecting online repurchase intention," Ind. Manag. Data Syst., 2014.

[14] S. Azar, S.N. Khan, and J. Shavaid, "Familiarity with online retailing," J. Dev. Areas, 2015.

[15] C.H. Park and Y.G. Kim, "Identifying key factors affecting consumer purchase behavior in an online shopping context," Int. J. Retail Distrib. Manag., 2003.

[16] L.G. Schiffman, L. L. Kanuk, and H. Hansen, Consumer Behaviour: A European Outlook. 2012. 